other universities and colleges throughout Poland have reiterated the anger of the academic community at what one protestor called the "outrageous" amendments. Both the new Independent Students' Association (NZS) and the "old" Socialist Union of Polish Students have issued protest statements, but because of the summer vacation, so far only the $A G H$ students have had the chance to organize any action (their chapter of NZS has also declared "strike readiness"). NZS is still hoping for the situation to be resolved by negotiation. However, if necessary, it would take a referendum of its members on possible strike action as soon as the universities reconvene.

Dr Michal Pulawski, an assistant lecturer at the Jagiellonian University and chairman of its Solidarity chapter, who actually declared the alert, was interviewed on Polish radio last week. He again stressed that the Krakow academics hoped that commonsense would prevail and a strike would not be necessary. Nevertheless, he said, the proposed amendments introduced in spite of the ministry's pledges to submit the bill to the Sejm (parliament) without further changes would fundamentally alter the law. They relate, he said, to the financing of higher education, the right of higher educational institutions to teach a plurality of world views, and the ways of hiring and dismissing the employees of higher educational establishments. (The latter is a sensitive issue in Poland, where the academic purges of 1968 were a grim experience for the younger generation of intellectual activists.)

The academic community was particularly indignant, Pulawski said, about the way the changes had been introduced "without consultation and without discussion". Indeed, a back-up message from the Solidarity chapter at Krakow Polytechnic suggested that the ministry had deliberately tried to rush things through, granting the academics "barely one week" to make their stance known. Since strike readiness was declared at Jagiellonian University and AGH, talks have been resumed. Last week, meetings included a discussion of the controversial amendments between Professor Hieronim Kubiak, a secretary of the Central Committee of the Polish United Workers' Party. and the various university rectors, many of whom have been elected by the new democratic procedures which the amendments would, presumably, negate. During a lively encounter between the minister Dr Jerzy Nawrocki and journalists from the Club of Educational Publicists, Dr Nawrocki seemed to be preparing for a partial climb-down on the amendments. Nothing was final, he said; his ministry would "shortly" be considering all the views expressed, and would be starting a new round of discussions with the relevant trade unions and student organizations.

Vera Rich
Belgian nuclear energy

\section{Safety in question}

\section{Brussels}

Serious failings in Belgium's nuclear safety policy have been brought to light in a new report. Commissioned by the Belgian government from the European Commission pool of nuclear experts, the report describes as "unhealthy" the manner in which the new plants Doel 3 and Tihange 2 are being constructed.

The report points out that in Belgium no safety survey is carried out on a nuclear power station until shortly before the plant goes active. By this time any outside expert advice is virtually useless, for either the plant cannot be altered, or at best only an uneasy compromise can be reached.

Ironically, the Belgian government had promised to tighten up nuclear power security following the Three Mile Island accident, but little has happened since then. The European Community experts now propose that Belgium should adopt the American procedural system whereby constructors of a nuclear power station must submit an initial safety study on which outside experts can suggest improvements. Then, before the plant goes into operation, a second study is carried out to demonstrate that the existing safety regulations and the new recommendations have been adhered to.

So far the Belgians have rejected this approach on the grounds that it takes too long and is too complicated.

The nuclear power industry's problems do not stop there. The International Atomic Energy Authority has already reprimanded Belgium for not engaging the 50 personnel it considers necessary to deal with matters of nuclear safety. The environmental group, Greenpeace, has been trying to stop vessels leaving Zeebrugge harbour with nuclear waste. And the 17 technicians at present working in Belgian plants are now threatening to go on strike because of a dispute over how the power stations are being run.

The workers are employed by a private company, Vincotte, which the Belgian socialist parties are trying to have replaced by a public authority. The Belgian government has been unable to reach agreement on this point and instead last month created two new departments in the Ministry of Work and Employment and the Ministry of Public Health, with responsibilities including the supervision of the work done by Vincotte. The money for this would come out of a special tax on the electricity produced.

This arrangement has so incensed the technicians at Vincotte that they have given notice of their intention to down tools. Furthermore, Vincotte's director has stated publicly that all power has now passed into the hands of those who do not have the necessary knowledge.

Jasper Becker

\section{Change at OSTP}

President Reagan's science adviser, Dr George A. Keyworth, has announced the reorganization of the Office of Science and Technology Policy (OSTP), which he heads. Two of the three previous associate directors under Dr Keyworth's predecessor, Dr Frank Press, will be staying on. Dr Benjamin Huberman, previously associate director for national security, space and international affairs, becomes deputy director of OSTP. And Dr Dennis Prager, who had been associate director for human resources and social and economic services, becomes assistant director for life science and institutional relations.

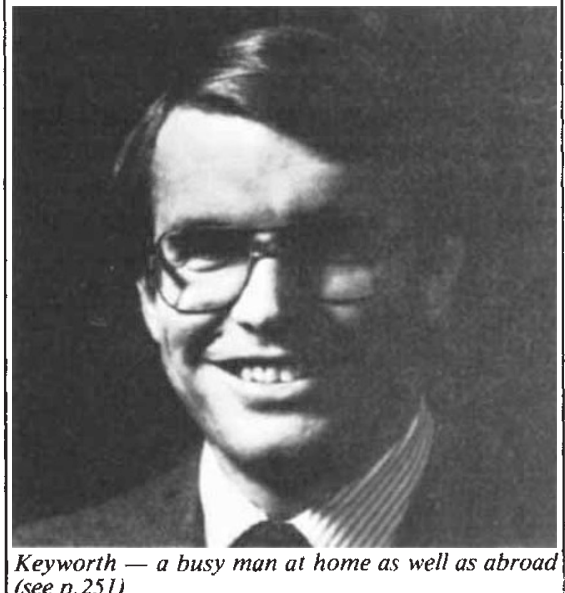
(see p.25I)

Four others have been appointed as assistant directors - John Marcum (energy and natural resources); Victor Reis (national security); Edward McGaffigan (international affairs); and Douglas Pewitt (general science). Major Thomas Johnson has been appointed a special assistant to Dr Keyworth, and is expected to be involved in issues concerning military technology.

David Dickson

\section{US science policy}

\section{Room at the top}

\section{Washington}

Members of the National Science Board (NSB) - the group of scientists appointed by the President to be responsible for the policies of the National Science Foundation (NSF) - have begun to debate whether they should play a more active role in national discussions on science and technology policy, urged on by their chairman, Dr Lewis Branscomb. Chief scientist at IBM, and at one time widelytipped as President Carter's science adviser, Dr Branscomb has made little secret of his feeling that, rather than concern itself strictly with the research and education programmes supported by the foundation, the board should tackle broader policy issues such as the health of US technology and science and engineering education in general.

Other members of the board are less cer- 